Mitteilungen der Österreichischen Geographischen Gesellschaft,

152. Jg. (Jahresband), Wien 2010, S. 63-85

\title{
A Pirate Paradise - \\ Underlying Causes and Key Challenges in Countering Piracy off the Horn of Africa
}

\author{
Clive SCHOFIELD, Wollongong (Australia)*
}

with 1 Fig. in the text

\section{Contents}

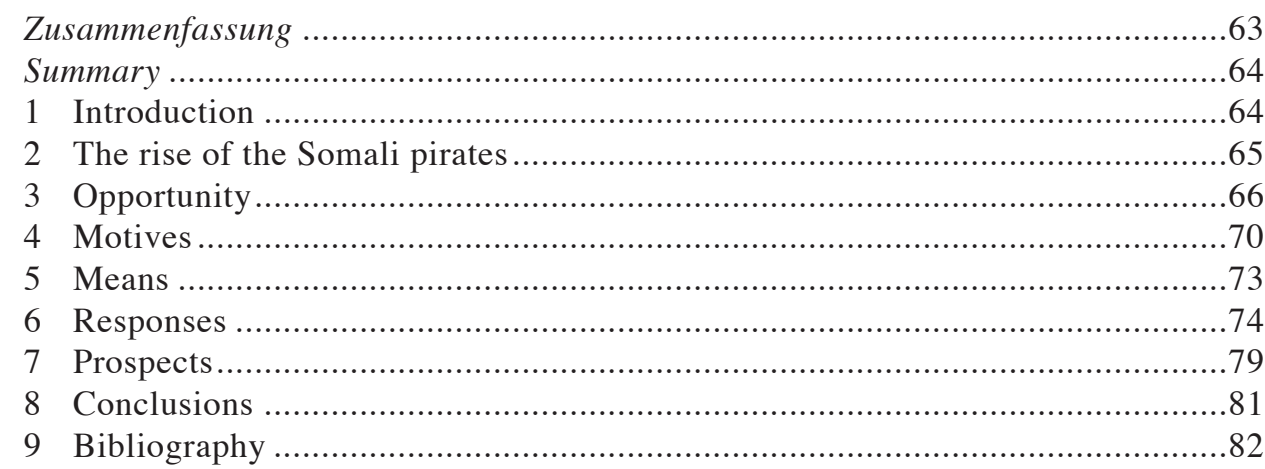

\section{Zusammenfassung}

Ein Piratenparadies - Hintergründe und wichtige Herausforderungen bei der Abwehr der Piraterie vor dem Horn von Afrika

Piraterie und bewaffneter Raubüberfall auf Schiffe vor dem Horn von Afrika haben in den letzten Jahren trotz aufeinander abgestimmter internationaler Gegenmaßnahmen deutlich zugenommen. Der Artikel beschreibt das starke Ansteigen der Piraterie, besonders vor den Küsten Somalias, bevor er die Hintergründe dieses Phänomens untersucht. Er unterzieht sodann die internationale Reaktion auf die wachsende Gefahr durch Piraten vor dem Horn von Afrika einer Kritik, um schließlich die Zukunftsaussichten zu beleuchten.

* Dr. Clive SchofIELD, Director of Research and QEII Research Fellow, Australian National Centre for Ocean Resources and Security (ANCORS), University of Wollongong, Wollongong, NSW 2522, Australia; E-mail: clives@uow.edu.au,http://www.ancors.uow.edu.au/. Dr. Schofield is the recipient of an Australian Research Council QEII Fellowship (DP0666273). 


\section{Summary}

The incidence of acts of piracy and armed robbery against shipping off the Horn of Africa has increased markedly in recent years despite concerted international counterpiracy efforts. The paper traces the precipitate rise in acts of piracy, especially off the coasts of Somalia before examining key underlying causes for this phenomenon. The paper then critiques the international response to the increasing piracy threat off the Horn of Africa before examining prospects for the future.

\section{Introduction}

In 2008 the number of incidents of piracy and armed robbery at sea that took place off the coast of the Horn of Africa surged, increasing by over $200 \%$. This threat to freedom of navigation through a key maritime route for international trade - linking Europe and Asia from the Mediterranean, through the Red Sea (via the Suez Canal) to the Indian Ocean - prompted an at first glance impressive response from the international community. Warships were rushed to the region by multiple, and diverse, states in order to guard threatened shipping and engage in counter-piracy activities. Despite this unprecedented international cooperative naval effort, the piracy threat off the Horn of Africa has far from disappeared. Indeed, the number of piratical incidents off the Horn of Africa almost redoubled from 2008 to 2009.

Why has piracy off the Horn of Africa flourished? Further, why have the pirates, predominantly armed with only light weapons and operating from small boats, apparently been able to frustrate the combined efforts of some of the world's most powerful and sophisticated naval vessels? The article addresses these questions by, first, briefly tracing the rise of the Somali 'pirates' and clarifying issues relevant to the use of that term before providing an assessment of the underlying factors that, it is submitted, are critical to an understanding the Somali piracy phenomenon and the challenges that face those wishing to resolve it. These factors are addressed under three broad headings: opportunity (geopolitical and historical context and spatial dimensions, including the critical influence of marine and coastal geography), motives (drivers arising from humanitarian issues, enduring poverty and environmental/resource insecurity) and means (outlining developing pirate operations and tactics). The paper then turns to a brief outline and critique of the efficacy, or otherwise, of the international response to piracy off the Horn of Africa, before considering some of the practical approaches that merchant vessels have taken themselves to ward off the threat of pirate attack. Finally, the article offers some considerations on prospects for the future in the troubled waters of the north-western Indian Ocean. 


\section{The rise of the Somali pirates}

The problem of piracy-style attacks against shipping off the Horn of Africa is by no means new. Although there has been a surge in piratical attacks off the Horn of Africa in the last two years, the problem of attacks on shipping off the Horn of Africa has been almost two decades in the making having largely emerged from the breakdown in law and order in Somalia post-1991 (see below). Indeed, over 700 attacks against ships were recorded in the period 1993-2005 (vON HoESSLIN 2006). While there was a noticeable dip in attacks on shipping off the Somali coast in late 2006, pirate attacks subsequently escalated (IMB 2007, p. 24).

During 2007 pirate attacks off Somalia more than doubled, while hijackings rose to a high of 31 . The following year, 2008, witnessed a distinct surge in piratical activity, leading to an increase in attacks of nearly $200 \%$ over the previous year (IMB 2009, p. 26). According to the International Maritime Bureau (IMB), Somali waters accounted for 111 reported pirate attacks in 2008, resulting in 42 successful hijackings (close to $40 \%$ of the 293 attacks reported globally) (BEVEGE 2009). Despite unprecedented multilateral counter-piracy efforts especially from mid to late 2008 , far from being reduced, let alone eradicated, the number of attacks on ships continued to increase in 2009. The total number of incidents attributed to the Somali pirates during 2009 was 217 with 47 vessels hijacked and 867 crewmembers taken hostage (PoTGIETER \& SCHOFIELD 2010, p. 96).

As a result the waters of the Gulf of Aden and off Somalia's eastern coast in the Indian Ocean have become the most dangerous in the world, more so even than the other main loci of piracy attacks in recent years such as the Indonesian and Philippines archipelagos and the Malacca Straits in Southeast Asia, the Bay of Bengal and the Gulf of Guinea. Indeed, in 2009 Somalia accounted for more than half of piracy incidents globally (Potgieter \& Schofield 2010, p. 96).

\section{Pirates versus sea robbers}

The international legal regime to deal with piracy developed in direct response to the 'pirate scourge' in the $18^{\text {th }}$ and $19^{\text {th }}$ centuries and has been progressively codified. The United Nations Convention on the Law of the Sea (LOSC) of 1982 (UnITED NATions 1983) provides the generally accepted legal framework governing the law of the sea, including piracy. LOSC has gained widespread international recognition and at the time of writing 161 states had become parties to it (UNITED NATIONS 2010). Under LOSC, which is generally taken to be reflective of customary international law on the issue, states parties are committed to cooperate in the suppression of piracy on the high seas (LOSC, Article 100). Key elements of piracy, as defined under Article 101 of LOSC, include criminal intent, the use of force, the taking over of a vessel against the wishes of its master, and the robbery of cargo, the possessions of those on board, or even the vessel itself (O'Connell 1984, pp. 968-970). Piracy also extends to the operation of a pirate ship which is a ship used to commit piratical acts (LOSC, Article 103), a provision that encompasses the use of, for example, 'mother ships' (see below). An important distinction is that piracy is undertaken for private ends and 
the term does not cover politically motivated acts (CHurchill \& Lowe 1999, p. 210).

One notable oddity in the international law definition of piracy, however, is that, in accordance with Article 101 of LOSC, piracy only refers to acts taking place outside the territorial sea. A key achievement of the LOSC framework was that it established clear spatial limits to national claims to maritime jurisdiction. Under the terms of Article 3 of LOSC, the breadth of the territorial sea may be "up to a limit not exceeding 12 nautical miles' measured from baselines along the coast. As many piracy-style acts in fact take place in close proximity to the coast, the term 'piracy' is often misapplied. In international law terms such piracy-like act taking place within the territorial sea should instead be referred to as 'armed robbery against ships'. An added complication in the Somali context is that Somalia retains a claim to a 200 nautical mile territorial sea which was first made in 1972 , despite the fact that it became a party to LOSC in 1989 (Republic of Somalia 1972). The failure to revise or 'roll back' this excessive claim to reflect the international norm of 12 nautical miles is perhaps unsurprising given Somalia's lack of a functioning central government since 1991. Somalia's broad territorial sea has been subject to diplomatic protests internationally and is generally not recognised by other states (RоACH \& SмIтн 1996, pp. 158-161).

In contrast to the definition contained in LOSC, the IMB has adopted a more allencompassing definition of piracy as, 'an act of boarding any vessel with the intent to commit theft or any other crime and with the intent or capability to use force in the furtherance thereof' (IMB 2009, p. 3). The broader IMB definition is used here.

\section{Opportunity}

\subsection{Geopolitical context: State failure and maritime insecurity}

Fundamentally the key causes of Somali piracy lie ashore. Piracy essentially emerged off the Somali coast following the fall of the Siad BARRE regime in 1991. The Somali central government collapsed and large swaths of the country have been ruled by clans, warlords and, more recently, radical Islamic insurgents, ever since. Somalia is therefore generally regarded as the prime example of a failed state and has become a by-word for chronic political instability, anarchic factional violence, grinding poverty and humanitarian crisis. Instability, insecurity and the near absence of law and order on land has, unsurprisingly, spilled offshore.

That said, the prevailing view of Somalia as a whole as an ungoverned and essentially ungovernable 'basket case', at least partially misrepresents the situation on the ground as parts of Somalia at least have enjoyed relative peace and security over a considerable length of time. In particular the 'Republic of Somaliland', which declared its independence from Somalia on 18 May 1991, arguably possesses many of the key attributes of statehood (a defined territory, population and functioning government featuring civil and security services, judiciary and democratic elections) that Somalia itself evidently lacks (Hoyle 2000, p. 88). There has been great resistance internationally to formally recognising Somaliland's independence and thereby 
sanctioning the political and territorial fragmentation of Somalia. In large part this reluctance to recognise Somaliland reflects fears of opening up a 'Pandora's box' of claims leading to the disintegration of post-colonial states in Africa and elsewhere. Consequently, Somaliland's independence has yet to be recognised by another state (SCHOFIELd 2008, p. 103).

The northeastern part of Somalia, that is, around the tip of the Horn of Africa, features a further quasi-independent entity, the self-styled 'Puntland State of Somalia'. Puntland has long sought autonomy within, rather than outright independence from Somalia. In August 2009, Puntland's autonomy within Somalia was formalised through an agreement between its government and Somalia's Transitional Federal Government (TFG) (SomaliPress 2009). The uneasy nature of the relations between the two sides was, however, emphasised by the subsequent disputes that erupted between them over the precise meaning and implementation of the autonomy agreement (VOA News 2009). Puntland has been characterised as a key haven and centre for pirate activities (Harding 2009). Puntland authorities have frequently declared their determination to eradicate the pirates operating from its territory, and called for international support to help them in this endeavour (GRESTE 2009). However, these pleas have thus far proved to be largely in vain, in large part because of concerns on the part of potential donors over corruption and the potential for funds and equipment supplied being diverted for use by pirates or even insurgent/terrorist interests (Ross 2009).

Despite areas of relative stability, large parts of Somalia do remain in the control of clans, warlords and insurgents. International efforts to promote national reconciliation and to resurrect a central government for Somalia as a whole led to the creation of the above-mentioned TFG under UN auspices in August 2000. These efforts have proved largely unsuccessful with the TFG proving to be a deeply divided entity with little influence on the ground in Somalia (ScHOFIELD 2008, pp. 103-104).

The latter half of 2006 did, however, see significant developments when a loose coalition of both moderate and radical Islamic forces, the Union of Islamic Courts (UIC) succeeded in taking control over much of southern Somalia (MEsoy 2006, p. 19). The UIC's strict imposition of Sharia law had a strong influence on the law and order situation in those areas under its control, and this, in turn, had a significant impact on piracy. The UIC succeeded in creating a hostile environment for piracy syndicates which were forced to radically curtail their operations. Consequently, piratical attacks off the Somali coast dwindled dramatically, with no attacks being reported from mid2006, when the UIC came to prominence, until November of that year (IMB 2007, pp. 17, 24-25).

These developments led directly to a military intervention into Somalia on the part of Ethiopia, backed by the United States, which was concerned over the rise of Islamic forces in Somalia and potential links to Al-Qaeda (SCHOFIELd 2008, p. 104). Whilst the intervention was a success in the sense that the Islamic Courts were, initially at least, defeated, the credibility of the TFG was severely undermined by its reliance on Ethiopian military support (Ethiopia being regarded by many Somalis as their traditional enemy). With the fall of the UIC the pirates essentially 'went back to business' with renewed vigour. 
The subsequent fragmentation of the UIC and the emergence of radical Islamic insurgent groups, notably al-Shabab (a transnational Islamic revolutionary group linked to Al Qaeda) and other Islamist-nationalist groups (collectively known as Hisbul Islamiyya), has led to escalating conflict. As a result, Ethiopian forces largely withdrew from Somalia in January 2009. Despite external support in the shape of arms shipments from the United States, by July 2009 the insurgents had largely succeeded in restricting the TFG to control of a few key locations in the capital, Mogadishu [Muqdisho], such as the Presidential palace, airport and port, amounting to only around $35 \%$ of the city overall. These areas are essentially those protected by the troops of the African Union Mission in Somalia (AMISOM) (Potgieter \& Schofield 2010, pp. 91-92). AMISOM has long suffered from being ill-equipped as well as significantly under its mandated strength $(8,000$ troops $)$ as promised troop contributions have been slow to materialise. This largely stems from the hazardous operating conditions experienced by the Mission which has increasingly been drawn into Somalia's internal conflicts. From only 3,400 troops in early 2009, AMISOM has gradually increased its strength to around 6,000 troops by mid-2010 and additional pledges were made at the African Union summit in Kampala in July 2010 that, if fulfilled, would bring AMISOM's strength up to 10,000 troops (CLOTTERY 2010).

Overall, the situation within Somalia remains unstable, violent conflict for control is ongoing and this lack of stability and security onshore has spilled in to the maritime domain.

\subsection{Spatial dimensions: A 'target rich' environment}

Somalia possesses the longest coastline of any mainland African state (around $3,300 \mathrm{~km}$ ) (SCHOfield 2008, p. 104). As noted above, Somalia has also advanced broad, if problematic, claims to maritime jurisdiction. The proximity of Somalia's neighbouring states, Djibouti to the northwest and Kenya to the south and, especially, Yemen to the north, serves to restrict Somalia's maritime claims somewhat whilst simultaneously giving rise to several, as yet unresolved, maritime boundaries with these states (BRADLEY et al. 2000, p. 288). Nonetheless, Somalia's long coastal front and expansive maritime claims have given rise to potential maritime claims estimated at 1.2 million $\mathrm{km}^{2}$ (Jennings 2001, p. 404) (see Fig. 1).

Directly to the north of Somalia lies the Gulf of Aden, through which commercial shipping must pass en route to and from the Red Sea 'chokepoint' of the Bab alMandeb Strait. This forms a key link in the route for maritime trade between Europe and the Asia-Pacific regions via the Mediterranean Sea, Suez Canal, Red Sea and Indian Ocean. Somalia's waters therefore lie in close proximity to shipping lanes that are vital to international trade and thus the functioning of the global economy. In this context it is worth highlighting that maritime transport continues to provide the 'backbone' of international trade with over $80 \%$ by volume being carried by sea (UNCTAD 2008, p. 8). This helps to explain regional and international concerns over maritime security off the Somali coast. Around 22,000 ships use this route annually, 


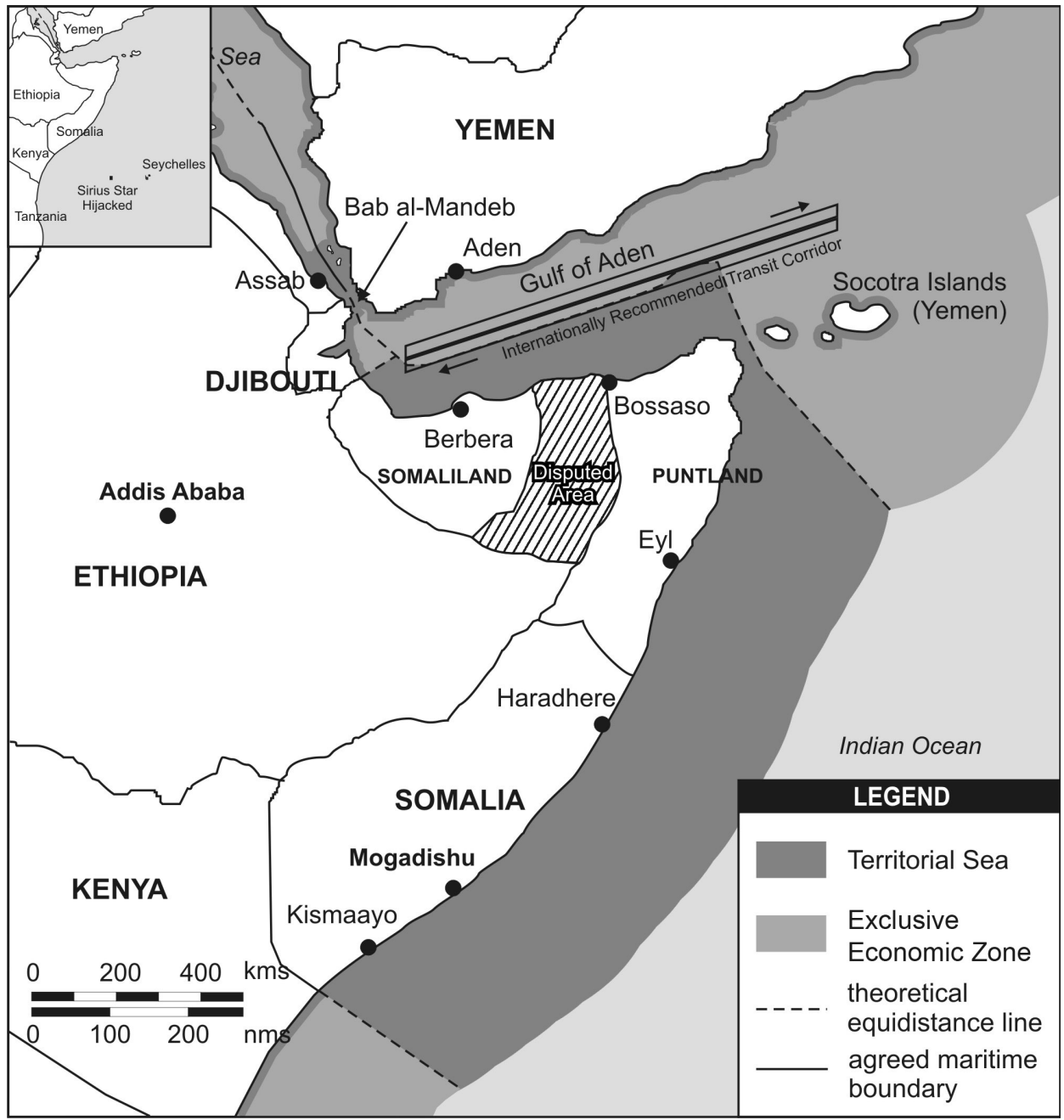

Fig. 1: The Horn of Africa and claims to maritime jurisdiction

carrying an estimated $8 \%$ of the world's trade, including over $12 \%$ of the total volume of oil transported by sea (IMO 2010).

In response to the rise in piracy attacks off the Somali coast the IMB recommends that all vessels 'keep as far away as possible from the Somali coast, preferably more than 600 nautical miles' offshore (IMB 2010). The constricted coastal geography of the Gulf of Aden as it narrows towards the Bab al-Mandeb at its western end makes this advice impossible to follow if the Suez Canal/Red Sea route is being used (see Fig. 1). The concentration of shipping transiting the Gulf of Aden made these waters 
attractive to pirates and thus especially dangerous for shipping. Consequently, the Gulf of Aden became a focus for the international counter-piracy effort. There is evidence, however, that the pattern of attacks has shifting in response. Increased patrols by international naval forces coupled with and counter-piracy precautions taken in these waters appear to have led to an evolution in pirate tactics, leading to attacks taking place increasingly far offshore in the Indian Ocean proper, well beyond Somali waters. These attacks significantly further offshore, away from the Gulf of Aden and inshore areas along Somalia's eastern littoral also illustrate how the pirates have developed greater reach in their operations, for instance by using 'mother ships' (see below). For example, on 10 November 2009, an oil tanker, the BW Lion, was attacked around 1,000 nautical miles off the Somali coast (400 nautical miles northeast of the Seychelles) (BBC 2009a). Consequently, the scale of the challenge for international naval vessels tasked with counter piracy is daunting - the increased reach of the pirates meaning that their operating area has expanded to at least two million $\mathrm{km}^{2}$ of ocean space.

\section{Motives}

\subsection{Poverty and personal gain}

The primary objective of Somali pirates is to take control of vessels attacked and take the crew hostage with a view to negotiating a ransom payment (termed 'KnRs' standing for 'kidnap and ransom'). The purpose of the Somali pirates is therefore personal gain rather than the pursuit of a political objective and in that sense these acts constitute piracy in the classic sense. In large part this reflects the near-two decades of profound social and economic dislocation and suffering endured by the Somali people since the collapse of Somalia's central government in 1991, coupled with multiple droughts resulting in famine and interruptions to the delivery of humanitarian aid caused by pirate attacks. Life expectancy in Somalia is estimated to be 46 years, while a quarter of the children die before the age of five (WFP 2010). In short, a strong contributing factor to Somali piracy is the profound poverty and desperation of large sections of the Somali population. Many Somalis are near destitute with around one third of the country's 10 million strong population are dependent on food aid (PotGIETER \& SCHOFIELD 2010, pp. 99-102).

The situation on the ground in Somalia continues to be dire from a humanitarian standpoint. For example, in May 2010 the UN RefugeE Agency (UNHCR) reported that an estimated 200,000 Somalis had been displaced in the early months of 2010 alone, adding to approximately 550,000 Somali refugees beyond Somalia's international boundaries and 1.4 million internally displaced people (UNHCR 2010). These factors coupled with the lack of a functioning central government and law enforcement authorities contributing to a breakdown in law and order provide the impetus for the increase in piratical attacks off the Somali coast. In this context the huge sums to be made from piracy (see below) are simply too enticing for many Somalis to resist. 


\subsection{Disenfranchisement}

A further important but generally under-reported, factor underlying the rise of Somali piracy is the fact that many Somalis feel disenfranchised and exploited by foreign powers. For example, the Somali coast has been used as a site for the dumping of toxic, including radioactive, waste from abroad. Furthermore and of particular note here is the fact that foreign trawlers have exploited Somalia's fisheries with impunity for years (UNEP 2006).

As noted above, Somalia's long coastline and broad maritime claims give rise to a huge maritime jurisdiction. Within Somali waters, the Somalia current marine ecosystem generates an intense upwelling of nutrient-rich cold waters. As a result, Somali offshore areas are productive in terms of marine living resources, especially in the Indian Ocean context. These marine living resources include high-value fish stocks such as tunas which are particularly attractive target species for foreign fishers (SCHOFIEld 2008, pp. 108-109).

In the absence of any national maritime surveillance and enforcement effort following the collapse of the Somali state, these waters have proved vulnerable and too tempting to foreign poachers. The presence of these distant water fleets fishing with impunity in Somalia's largely unprotected waters has led to concerns regarding overexploitation and the potential for collapse of Somali fish stocks (FAO 2010). It is, however, impossible to determine this with any certainty, given the lack of reliable statistics on catches within Somalia's maritime jurisdiction and the undocumented nature of foreign fishing activities in Somali offshore areas.

The United Nations Food and Agriculture Organization (FAO) estimates there are '700 foreign-owned vessels fully engaged in unlicensed fishing in Somali waters' (FAO 2010). It is unclear, however, what impact the rise in incidence of piracy in Somali waters has had on the activities of foreign fishing fleets. There have been reports that foreign fishers have engaged in destructive fishing practices such as bottom trawling, endangering Somali fishing stocks and have also aggressively sought to chase local fishermen away from productive fishing grounds, using high-pressure or boiling water hoses and even firearms for this purpose (JenNings 2001, pp. 409-410; KulmiYe 2001; Lehr \& Lehmann 2007, pp. 13-14; Mwangura 2005; Schofield 2008, pp. 110-111).

It has been estimated that the value of these uncontrolled foreign catches from Somalia's maritime areas vary from in excess of US\$90 million to US\$300 million per year. If the latter figure is the case then this is roughly three times the sum said to have been paid out by the shipping industry in ransoms to the pirates in 2008 (LEHR \& Lehmann 2007, p. 13; Schofield 2008, p. 108; von Hoesslin 2006). Indeed, it has been observed, not without bitterness, that foreign fishing vessels are in fact taking considerably more protein out of Somalia's waters than the international community are supplying to Somalia in the form of humanitarian food aid (JENNINGS 2001, p. 407).

These foreign fishing vessels reportedly come from the immediate region, including Kenya, Pakistan, Saudi Arabia, Sri Lanka and Yemen as well as from further afield, including Belize, France, Honduras, Japan, South Korea, Spain and Taiwan (Schofield 2008 , p. 108). It is especially ironic that a number of the nations that are presently contributing warships to the anti-piracy flotillas patrolling the waters off the Horn 
of Africa, are themselves directly linked to the foreign fishing vessels that are busily plundering Somalia's offshore resources (SCHOfield 2009). The international naval presence in the region is not, however, tasked with restraining such illegal, unreported and unregulated (IUU) fishing activities in Somali waters.

It is the case that the foreign fishing catches within Somalia's claimed 200 nautical mile zone are arguably not illegal in that Somalia, as mentioned above, claims a 200 nautical mile breadth territorial sea rather than an exclusive economic zone (EEZ) (something Somalia has yet to claim) and, as such, many states do not recognise Somalia's claims. Nevertheless, even if these activities are technically not illegal in international law terms, they are certainly perceived as the theft of Somalia's rightful marine living resources by many Somalis. It has also allowed pirates to try and justify their actions - several pirate groups style themselves 'coastguards' or 'marines' and characterise their ransom demands as 'fines' (SCHOFIELD 2008, pp. 109-110). Whilst foreign poaching of Somali fish in no way justifies violent acts of piracy or armed robbery at sea and that the pirates' targets are not confined to foreign trawlers, the systematic plundering of Somalia's resources by foreign fishing fleets remains a potent underlying and motivating factor in the Somali piracy phenomenon. That said, removing the illegal fishing problem would not, in all likelihood, lead to a resolution of the piracy problem as Somali piracy now represents big business (ScHOFIELD 2009).

\subsection{Rich pickings}

A key contributing factor underlying the rise in piracy off the Horn of Africa is the fact that it has proved so profitable for the pirates. Critically, the international shipping industry and insurers have proved willing to pay out multi-million dollar ransoms for the release of hijacked vessels and cargoes and kidnapped crew with estimates of the ransoms paid to pirates in 2008 alone ranging from US\$30 million to US\$150 million according to the Kenyan Foreign Minister (AFP 2009a; The Telegraph 2009; AP 2009). Piracy has, consequently, developed into an especially lucrative business. Indeed, it has been suggested that the 'going rate' for the release of a ship and crew was around US\$1 million in 2008 but roughly doubled in 2009 (SAUL 2009). Indeed, certain ships can fetch significantly higher ransoms as can be illustrated by reference to a few prominent examples.

For example in September 2008 the Ukrainian (though Belize registered) freighter MV Faina, carrying 33 Russian-made T-72 tanks, spare parts and ammunition destined for the Kenyan army was hijacked (BBC 2008). A US\$3.2 million ransom was reportedly delivered to the pirates in return for the release of the vessel, crew and cargo in early February 2009 (BBC 2009b). Yet more startling was the 15 November 2008 hijacking of the Sirius Star, a brand-new, Saudi owned super tanker carrying a cargo of two million barrels of oil valued at in excess of US\$100 million (BBC 2008b). The stunning seizure of such a large (330 m and 318,000 dead weight tons) and modern (launched in April 2008 and costing an estimated US\$150 million to build) vessel with such apparent ease grabbed headlines around the world. Once again the vessel, crew and cargo were released once a ransom, estimated at US\$3 million was paid to the Somali 
pirates on board the vessel on 9 January 2009 (BBC 2009c). Subsequently, Somali pirates captured another super-tanker, the Maran Centaurus which was seized on 29 November 2009, together with a crew of 29 and a cargo of around two million barrels of crude oil (BBC 2009d). A ransom reported to be between US\$5.5 and 7 million was dropped onto the deck of the hijacked vessel from a light plane on 18 January 2010, leading to the vessel's release (MALKHADIR 2010). Further, on 6 November 2010, it was reported that Somali pirates had been paid ransoms totalling US\$12.3 million for the release of two ships - US\$ 9.5 million for the release of the Samho Dream, a South Korean oil tanker carrying crude oil worth an estimated US\$ 170 million, and US\$ 2.8 million for the Singaporean-flagged Golden Blessing (BBC 2010a). At the time of writing, the ransom received by the Somali pirates for the release of the Samho Dream represents the largest yet paid for the release of a captured vessel, crew and cargo.

Although the payment of ransoms has been criticised as simply encouraging further acts of piracy, it appears that the shipping industry has been willing to shoulder the financial burden of Somali piracy in terms of ransoms and increased insurance costs as an unpleasant but acceptable price for transiting the waters off the Horn of Africa. Such additional costs are inevitably passed on to consumers. This perhaps recognises the reality that while it is clear that piracy and attacks against shipping in the Horn of Africa region have escalated alarmingly since 2008 , it is also the case that at present these incidents only affect a small proportion of the shipping traversing the waters off the Horn of Africa (under one per cent). While the payment of ransoms is entirely understandable where the lives of crew members are under threat, this necessarily represents a powerful incentive, encouraging further piratical attacks (ScHOFIELD \& W ARNER, forthcoming). This is especially the case given widespread poverty ashore, coupled with the absence of compelling deterrents to engaging in piracy (see below).

\section{Means}

Given the longstanding, dire humanitarian situation in Somalia, and the lack of viable alternative occupations, pirate gangs have a large and enthusiastic pool of potential recruits who effectively have little to lose by engaging in illegal acts at sea. Among these recruits are former fishermen who offer maritime skills including navigation and small boat handling experience.

Somali piracy is distinct from the vast majority of attacks against shipping that occur elsewhere around the world, including other piracy hotspots such as the Bay of Bengal, Gulf of Guinea and in Indonesian waters. Rather than involving hit-and-run style attacks with the aim of robbing the ship's safe and relieving the crew of their valuables, attacks off the Somali coast often take place in broad daylight with the objective of seizing the ship as a whole. This is generally achieved through the use of small, fast boats or skiffs, equipped with high-powered engines. Increasingly, the pirates have access to high-tech equipment such as satellite phones and navigation gear (global positioning systems, GPS) (Potgieter \& Schofield 2010, p. 94). The pirates also have little difficulty in accessing their main weapons of choice - Kalashnikov 
automatic rifles (the ubiquitous AK47) and rocket-propelled grenades (RPGs) as, it is estimated that, there are in excess of two million such small arms in Mogadishu alone, which have predominantly been smuggled across the Gulf of Aden from Yemen (von Hoesslin 2006).

A common tactic is to open fire in order to try and make vessels slow or heave-to. Often multiple boats are used in 'swarm' or decoy type tactics. Somali pirates have also been known to use of fake distress calls as a ruse to lure unwary ships within range. Distinguishing between fake and genuine calls for aid can therefore prove problematic (as many Somalis seek to flee the country, particularly from Bossaso to Yemen, using often dilapidated and overloaded boats, real distress calls are by no means unheard of in these waters) (see Fig. 1). Alternatively, pirates have posed as distressed fishermen in need of water supplies or opted to hide among groups of fishing boats until their potential victims come within range (SCHOFIELD 2007).

It is also apparent that the Somali pirates have progressively enhanced their capabilities and altered their tactics over time. In particular the range of pirate operations has been significantly extended through the use of 'mother ships' (a larger vessel used as a base by smaller craft) or 'brother ships' (a larger skiff, filled with fuel, towing other skiffs) and this has led to a shift in the focus of pirate operations from the Gulf of Aden into the Indian Ocean proper (Potgieter \& Schofield 2010, p. 94). The hijacking of the Sirus Star, 450 nautical miles offshore, represents a striking example of this practice. As Admiral Mike Mullen, Chairman of the United States Joint Chiefs of Staff commented on 18 November 2008: 'I'm stunned by the range of it' (SMH 2009b). The Somali pirates also appear to have spread their operations to the southern Red Sea where a spate of attacks took place in mid-2010, culminating in the first hijacking of a vessel by pirates in the Red Sea in July 2010 (IMB 2010a). These incidents have, however, been at least partially attributed to climatic conditions. The onset of the monsoon season tends to make small boat handling difficult in the open ocean but less problematic in the more sheltered Red Sea, leading pirates to shift the geographical focus of their activities (IMB 2010a).

\section{Responses}

\subsection{International counter-piracy operations and cooperation}

As previously noted, multiple interested states rushed warships to the Horn of Africa region from late 2008. Naval vessels have been deployed not only from the traditional maritime powers of the United States, Russia and a number of European states (notably United Kingdom, Germany, France and Spain) as well as Canada and Turkey, but also from less anticipated and far-flung participants such as Australia, the People's Republic of China (engaging in its first long-range deployment), Malaysia, the Republic of Korea and Japan, as well as more local or regional states such as Pakistan, India and Iran. This has led to remarkable and unprecedented international naval 
cooperation designed to counter piracy, including the creation of multiple, interlocking cooperative naval operations in the region. In October 2008 NATO established a counter-piracy operation called Allied Provider (operation Ocean Shield from August 2009). In December 2008 the European Union initiated Operation Atalanta, including warships from ten countries (known as European Naval Forces or EU NAVFOR), while in January 2009 the United States established Combined Task Force (CTF) 151 (NATO 2009, paras. 64-73).

It is worth noting, however, that several states with naval assets operating in the region, for example China and Russia, have opted to remain outside the cooperative framework provided by these multilateral naval missions. However, anti-piracy efforts are coordinated and information shared under the Code of Conduct concerning the Repression of Piracy and Armed Robbery Against Ships in the western Indian Ocean, concluded in Djibouti in January 2009 (IMO 2010). Further, the navies deployed to the region have developed a number of practical cooperation and coordination mechanisms including monthly meetings of a forum termed the Shared Awareness and Deconfliction (SHADE) group which provides an opportunity for tactical coordination among representatives of the deployed navies and the shipping community (NATO 2009, para. 73; SCHOFIELD \& W ARNER forthcoming).

As noted above, a key practical difficulty facing the commanders of the naval vessels involved is the vast area to be patrolled, especially in view of the proven reach of the pirates, coupled with the speed of attacks. Even with the increased naval presence in the region, patrols cannot be everywhere and commonly as little as 15 minutes may elapse from attack detection to hijacking (AugEY 2009). The challenge facing the navies now patrolling the waters off the Horn of Africa is therefore to catch pirates in the act - an extremely difficult task. A further problem relates to how to tell with certainty who exactly the pirates really are. As noted above, pirates often masquerade as innocent (albeit heavily armed) fishermen. The mere possession of arms is not proof of piratical intent or guilt (almost every small vessel operating in these waters will carry arms for self-protection) (SCHOFIELD \& WARNER, forthcoming).

To cope with the sheer geographical scope of the area of operations off the Horn of Africa, a range of approaches have been developed. One early tactic employed was to provide escorts for threatened shipping, for example for United Nations World Food Program chartered cargo ships carrying humanitarian aid shipments to Somalia (Bevege 2009; Potgieter \& Schofield 2010, pp. 101-102). In order to better protect shipping an Internationally Recommended Transit Corridor (IRTC) has been established through the Gulf of Aden area, protected by ships from CTF 151, NATO and EU NAVFOR (NATO 2009, para. 73). However, even this does not guarantee security as vessels have been hijacked whilst passing through this supposedly safe corridor. Some states have also opted to embark detachments of Special Forces on merchant ships (SCHOFIELD \& W ARNER, forthcoming).

While it is easy to portray the international naval response as having failed in light of the fact that the number of piratical attacks off the Horn of Africa rose dramatically in 2009 as compared to 2008 (almost doubling), one guardedly positive development that arguably results from the international naval presence in the region, is that the 
proportion of attacks that resulted in the hijacking of a vessel fell substantially in the same period (from around $38 \%$ to $22 \%$ success rate for the pirates) (PotGIETER \& SCHOFIELD 2010, p. 96). It is also perhaps arresting to contemplate how dire the figures for attacks against shipping would have been had the international naval patrols not been operating in the region.

\subsection{United Nations resolutions}

These naval operations are backed and authorised by a series of UN Security Council resolutions under Chapter VII of the UN Charter. For example, notably Resolution 1816 (of 2 June 2008) authorises states cooperating with the Somali Transitional Federal Government to enter the territorial waters of Somalia and use 'all necessary means' to repress acts of piracy and armed robbery at sea, though in a manner 'consistent with the relevant provisions of international law' (UNSC 2008a). Security Council Resolution 1838 (7 October 2008) reinforces the earlier Resolution and 'calls upon all States interested in the security of maritime activities to take part actively in the fight against piracy on the high seas off the coast of Somalia, in particular by deploying naval vessels and military aircraft' (UNSC 2008b). UNSC Resolution 1816 was renewed through the adoption of Resolution 1846 on 2 December 2008 which extended the international community's mandate for another 12 months (UNSC 2008c). A further Resolution, no. 1851 of 16 December 2008 authorised measures to facilitate more effective law enforcement and also permitted the international community to operate not only within Somali waters but also within the land territory of Somalia which is used to plan, facilitate or undertake acts of piracy and armed robbery (UNSC 2008d). Additionally the UN Security Council has recently adopted Resolution 1918 of 27 April 2010 which is detailed below (UNSC 2010).

\subsection{Legal, logistical and political dilemmas}

If pirates are captured the question then becomes one of what to do with them. As there is no functioning central government operating in Somalia, there is no authority to hand captured pirates over to. However, as noted, piracy has long been recognised as a crime against the whole world and one of the limited number of crimes subject to universal jurisdiction which is punishable by any state regardless of the nationality of the victim or perpetrators. Consequently, acts of piracy could be tried under the capturing state's laws - if they should choose to do so.

In practice the reality is that a number of legal, logistical and political obstacles arise which have tended to discourage capturing states from prosecuting pirates in their own courts. While piracy constitutes a universal crime, by no means every state has adequate and up-to-date domestic laws addressing this issue and it was notable that the above-mentioned UN Security Council Resolution 1918 specifically calls on UN member states to criminalise piracy in their national laws and to detain and 
prosecute suspected pirates off the coast of Somalia in accordance with international human rights law (UNSC 2010). Further, if convicted, the pirates would then have to be imprisoned in the capturing state and this actually represents a considerable financial burden. Moreover, even when such individuals have served their time, it may be difficult to return them to Somalia on human rights grounds as there is a legitimate concern that they may be subject to torture or execution on their return. All of these factors represent disincentives to action (SCHOFIELD \& W ARNER, forthcoming).

Consequently, interested states have sought to circumvent these problems through concluding bilateral transfer agreements with states within the region in order to facilitate the investigation and trial of alleged pirates there instead and side-step the need to transfer alleged pirates to their own jurisdictions. The EU, UK and USA have all signed such agreements with Kenya (WESTCOTt 2009, W ARDHEERNEws 2009) whilst analogous accords have also been reached with the Seychelles and Tanzania (THE GLOBAL HERALD 2010, IOL News 2010). This expedient option is, however, problematic given the overloaded nature of, notably, the Kenyan criminal justice system (Westсотт 2009). For example, in early 2010 it was stated in a House of Lords report to the UK parliament that 117 alleged pirates held in Kenyan custody were awaiting trial (House of LoRds 2010). This led to Kenya announced in April 2010 that it intended not to accept any more pirates for prosecution unless other countries gave security guarantees and shared the costs involved (Houreld 2010). It is also the case that legal challenges have already arisen over whether Kenya can try pirates that it did not apprehend for crimes outside its jurisdiction. Similarly, there have been allegations of physical abuse of detainees in Kenyan prisons, laying the transferring states open to accusations of facilitating human rights abuses. Furthermore, there exist practical difficulties for the transferring state as personnel involved in the capture of alleged pirates may be required to give evidence at their trial (SCHOFIELD \& W ARNER forthcoming). A specialist court has now been opened in Kenya to clear the backlog of pirates to be tried (Еросн Times 2010).

In view of these challenges, some states, for instance the United States, have opted to send pirates to their own jurisdictions for investigation and prosecution ( $\mathrm{KU} 2010)$. Further, certain states have gone to the trouble to extradite pirates captured by other states in order to try pirates in their own jurisdictions. The Netherlands requested the extradition of five pirates captured by a Danish navy frigate participating in the NATOled Combined Task Force 150 when they attacked a Dutch cargo vessel in the Gulf of Aden on 2 January 2009 (AFP 2009b). These pirates were tried in the Netherlands and sentenced to five years imprisonment in June 2010 (JURIST LEGAL NEWS AND RESEARCH 2010). Emphasising the point made above concerning updating relevant legislation, the convictions in this case were secured for contravention of a $17^{\text {th }}$ century Dutch law against 'sea robbery' (The GuARDian 2010).

As a result of these practical obstacles to bringing pirates to justice, a number of countries with naval vessels deployed to the region are effectively operating a 'catch and release' policy, simply confiscating the arms used but otherwise leaving the pirates to return another day - hardly an effective deterrent. 


\subsection{Practical responses}

In light of the evident and continuing threat to safety of navigation and the less than comprehensive nature of the international naval responses outlined above, mariners have developed and implemented a range of 'self help', counter piracy measures. The first and most glaringly obvious of these has been to reroute and avoid the threatened area. As noted, the IMB recommends that passing vessels stay at least 600 nautical miles offshore. In order to fulfil this requirement it is clear that the Gulf of Aden and thus the Red Sea/Suez Canal route has be avoided. This necessitates a significant diversion (therefore incurring considerable additional transit costs) around the African continent by way of the Cape of Good Hope. It is worth noting, however, that even this option does not guarantee safety from pirate attack in light of the remarkable reach of the pirates, facilitated by their use of mother ships. A salient example in this context is the hijacked super tanker Sirius Star, mentioned above, which was seized 450 nautical miles off the Somali coast whilst en route from the Persian Gulf to the USA via the Cape of Good Hope route.

Generally speaking, large vessels such as tankers and modern container ships represent formidable targets for pirates seeking to board from small boats when under way. When moving slowly and when full-laden, however, such vessels become much easier prey. When fully laden the freeboard (that is, the distance from the surface of the water to the deck of the ship) on such vessels can be only 3-4 metres - a distance easily overcome with a grapnel and line. A further key factor is speed with vessels travelling at 18 knots and above generally considered to be immune to boarding from small boats, largely because of the bow wave and wake that they generate. Vigilance therefore becomes a critical issue as early detection of potential attackers allows the master of the threatened vessel to increase speed and engage in evasive manoeuvres. The IMB therefore also advises vessels traversing pirate-threatened waters to maintain a strict 24 hours radar and anti-piracy watch. This is not necessarily something that is easy to achieve given the scale of some modern vessels, coupled with the small crews that they tend to carry.

Early detection also provides the opportunity to mobilize anti-piracy responses. Such responses may involve the use of high-pressure water hoses and foam. They may also include the use of barbed or razor wire to make boarding more difficult. Similarly, key parts of the ship such as the bridge, engine room and crew accommodation area may be locked down to deny or delay access by boarders, potentially providing time for intervention by international forces before the pirates take control of the vessel. For example, the crew of the Russian tanker MV Moscow University locked themselves in a safe room when their vessel was attacked, allowing time for the ship to bee retaken whilst simultaneously denying the pirates hostages to bargain with (DANILOva 2010). More low-tech measures include the use of mannequins or dummy sailors to give the appearance that more crew/guards are on board the vessel than there actually are. Some vessels have also sought to alter their appearance, constructing fake wooden superstructures to enclose otherwise open deck areas (SмIтн 2010). The IMB urges all vessels transiting the pirate attack-prone waters off the Horn of Africa to follow 
industry Best Management Practice (BMP) designed to avoid, deter or delay piracy attacks on commercial shipping in the region (IMB 2010c).

Additionally, new technologies are increasingly being introduced such as electric fencing for shipping (though this is not suitable in all cases as electricity and flammable vapour makes for an explosive mix) and the use of 'sonic weapons' such as long-range acoustic devices (LRAD) - which generate noises at painful, but non-lethal decibel levels with the aim of disorienting and deterring potential pirates. Such a weapon was employed by the crew of the cruise liner Seabourn Spirit, as one of the counter-piracy measures when it was attacked on 5 November 2005. Although the Seabourn Spirit escaped without being boarded, one rocket-propelled grenade round did penetrate the hull, while another reportedly bounced off the ship's stern (SCHOFIELD 2007, p. 47; LeHr \& LeHMANn 2007, pp. 2-5).

The option of arming non-military vessels has, however, not generally been greeted with much enthusiasm from authorities or mariners alike. In certain circumstances, private security guards have been hired. For example, Somali militiamen have on occasion been recruited to guard vessels carrying humanitarian aid shipments. Similarly, the private, armed security guards on board the cruise liner Melody were crucial to fending pirates when that vessel was attacked in April 2009 (BBC 2009f). Alternatively, in certain circumstances States have embarked teams of Special Forces personnel on merchant vessels, usually of their own flag, to provide ship borne security (SCHOFIELD \& W ARNER, forthcoming; SMITH 2010). Rather more unconventionally, an entire naval vessel might be hired to provide escort duties. This notion may seem rather far-fetched, however, it has been pioneered by Danish shipping company A.P. Moller-Maersk which in early 2010 confirmed that it had hired a Tanzanian military patrol vessel to escort one of its ships from Dar es Salaam to Mombasa in 2008 (ThisDay 2010). The Danish firm reportedly paid the salaries of the Tanzanian People's Defence Force crew, as well as related bunker (fuel) costs.

\section{Prospects}

\subsection{Getting tough?}

Whilst in this day and age the idea of making the pirates 'walk the plank' or 'hanging them high' is off the agenda, at least as far as western navies are concerned, there are indications that international forces are becoming more robust in their actions against pirates. France has led the way in this context, responding to the hijacking of several French yachts off the Horn of Africa in a forthright manner, even though hostages have been involved. While these actions have generally met with considerable success, they have also come at a cost - in the storming of the yacht Tanit in April 2009, for example, although four hostages were freed, one hostage (and two pirates) lost their lives when the hijacked yacht was stormed by French Special Forces (BBC 2009e). This incident serves to underscore the risks involved in this type of intervention. Russian authorities 
responded in a similarly robust fashion in despatching special forces based their warship Marshal Shaposhnikov to successfully regained control of a Russian tanker, the MV Moscow University, on 6 May 2010, the day after its hijacking (DANILOva 2010). One of the eleven pirates involved was killed when the ship was retaken whilst the remaining apprehended pirates were then reportedly set adrift in an inflatable boat lacking navigational gear and were presumed to have subsequently drowned (BBC 2010b). The forceful approach adopted by the French and Russian authorities is in marked contrast to that of many other States who have generally proved reluctant to put the lives of hostages at risk.

International naval operations initially concentrated on counter-piracy measures in those areas most afflicted by pirate attacks, the Gulf of Aden and areas close to the Somali coast and developed a range of mechanisms to help protect shipping and safeguard freedom of navigation (notably through convoys and recommended, patrolled transit corridors). These measures met with some degree of success in that the number of pirate attacks in the Gulf of Aden declined. However, it is also clear that the pirates capabilities have improved, their tactics have evolved and the geographical focus of their attacks has shifted over time. Accordingly, international naval efforts have also developed to not only concentrate on defensive measures in terms of guarding threatened vessels but instead to focus on proactively pursuing and apprehending the mother ships that are vital to sustaining the remarkably long reach of some Somali pirate groups (IMB 2010c).

Arguably, there are some signs of progress in that the first nine months of 2010 witnessed a decline in terms of the proportion of pirate attacks that Somali pirates were responsible for globally. That said, Somali waters remained the most hazardous in the world, accounting for $44 \%$ of 289 reported incidents in the period January - September 2010. Further, Somali pirates were responsible for 35 of the 39 ship hijackings recorded in the same period (IMB 2010d).

\subsection{More effective legal remedies?}

As noted above, legal obstacles exist regarding bringing alleged pirates to justice. One suggestion has been the creation of a specialist or regional tribunal specifically for trying pirates, analogous to existing tribunals such as the International Criminal Tribunal for the Former Yugoslavia (ICTY) and the International Criminal Tribunal for Rwanda (ICTR). It remains questionable, however, whether piracy can be regarded as being in the same category of seriousness as genocide, war crimes and crimes against humanity and thus requiring a specialist tribunal. It also remains unclear who would fund such a body which would inevitably be costly to establish and run. That said, it is notable that through its, at the time of writing, most recent Resolution on Somali piracy, Resolution 1918 of 27 April 2010, the UN Security Council specifically requested the UN Secretary General to report on options for prosecuting and imprisoning those responsible for piracy and armed robbery at sea including the possibility of establishing a regional or international tribunal to deal with piracy cases (SCHOFIELD \& W ARNER forthcoming). 
A further option suggested by U.S. Secretary of State Hillary CLINTON in April 2009 involves the freezing pirate financial assets (HYER STANDARD 2009). While superficially this sounds promising, the reality is more problematic as the Somali pirate gangs do not appear to be especially well integrated into the global financial system. Nonetheless, the United States government has sought to pursue this approach through issuing Executive Order 13536 of 12 April 2010, 'Blocking Property of Certain Persons Contributing to the Conflict in Somalia' (United States 2010).

\section{Conclusions}

The collapse of Somalia as a functioning State is the key factor in the deterioration of maritime security in the Horn of Africa region. As a result of ongoing instability and violent conflict the humanitarian situation for the Somali people remains dire. Unfortunately there are scant signs of this scenario changing substantially in the near future. Driven by poverty and the plundering of Somali offshore resources, in the absence of governmental control on land to restrain criminal activities and allied to ready access to maritime skills and military hardware plus proximity to busy shipping lanes replete with tempting targets, it is little wonder that piracy has flourished off Somalia. The lack of stability and security onshore has spilled into the maritime domain.

Current responses to the Somali piracy phenomenon generally treat the symptoms rather than the root causes - how pirates are able to operate from secure safe havens on land and why individuals are driven to become pirates in the first place. Fundamentally there appears to be a lack of political will to address these, admittedly daunting, challenges on the ground. Ultimately, until peace, stable political governance and the rule of law are restored in Somalia, something that unfortunately seems to be far over the horizon, piracy seems set to continue off the Horn of Africa. This is not, however, to argue that the counter-piracy efforts made by the international community and the international naval flotilla operating off the Horn of Africa are without merit. The cooperative international naval effort, coupled with more stringent anti-piracy measures on the part of commercial shipping, have, it can be strongly argued, served to forestall even more attacks and, particularly, successful hijackings of vessels.

If Somali piracy initially emerged from disgruntled and disenfranchised fishermen seeking restitution, it has now evolved into a multi-million dollar business which has spawned relatively sophisticated, organised and equipped transnational criminal syndicates. Piracy attacks off the coast of Somalia are only likely to get worse with the tantalising prospect of substantial ransoms still a reality for the criminal gangs involved. The question arises as to whether the current mix of global responses to this problem is appropriate and well targeted. Given the lack of a compelling deterrent effect created by the presence of multiple navies in the region and the apparent readiness of the shipping industry to treat the ransoms as an operational cost to be passed on to consumers, this calls into question the long term efficacy of deploying naval vessels designed for high end war fighting operations to counter this threat. 


\section{Bibliography}

Agence France Presse (AFP) (2009a), US 5 ${ }^{\text {th }}$ Fleet Announces new international anti-piracy force, 8 January 2009.

Agence France Presse (AFP) (2009b), Dutch seek Extradition of Somali pirates, 15 January 2009. - http://www.google.com/hostednews/afp/article/AleqM5hMfTxjAVudEutFtdRutwzyR

Associated Press (AP) (2009), U.N. Group charts new course against piracy, 14 January 2009, in CHINFO News Clips, 9 and 15 January 2009.

Augey P.-E. (2009), Indian Ocean Maritime Security Cooperation: the Fight Against Piracy off the Somali Coast. In: Indian Ocean Maritime Security Symposium, Australian Defence College, Canberra, 15-17 April 2009.

Bevege A. (2009), NATO warship hunts Somali pirates, escorts food aid, Reuters, 12 June 2009. - http://www.reuters.com/article/latestCrisis/idUSLC801321

Bradley R.E., Pratt M.A., Schofield C.H. (2000), Jane's Exclusive Economic Zones 2000-2001. Coulsdon, Jane's Information Group.

British BroadCAsting Corporation (BBC) (2008a), Somalia's pirates seize 33 tanks, BBC News Online, 26 September 2008. - http://news.bbc.co.uk/2/hi/africa/7637257.stm

British Broadcasting Corporation (BBC) (2008b), Seized tanker anchors off Somalia, BBC News Online, 19 November 2008. - http://nes.bbc.co.uk/2/hi/africa/7735507.stm

British Broadcasting Corporation (BBC) (2009a), Midocean pirate attack on tanker, BBC News Online, 10 November 2009. - http://news.bbc.co.uk/2/hi/africa/8350850.stm

British BroadCAsting Corporation (BBC) (2009b), Somali pirates "free arms ship", BBC News Online, 5 February 2009. - http://news.bbc.co.uk/2/hi/africa/7871510.stm

British BroadCASting CoRporation (BBC) (2009c), Saudi tanker 'freed off Somalia', BBC News Online, 9 January 2009. - http://news.bbc.co.uk/2/hi/africa/7820311.stm

British Broadcasting Corporation (BBC) (2009d), Somali pirates capture supertanker taking oil to US, BBC News Online, 30 November 2009. - http://news.bbc.co.uk/2/hi/ africa/8385845.stm

British Broadcasting Corporation (BBC) (2009e), French hostages freed off Somalia, BBC News Online, 10 April 2009. - http://news.bbc.co.uk/2/hi/7994201.stm

British BROADCASTING CORPORATION (BBC) (2009f), Italian cruise ship foils pirates, BBC News Online, 26 April 2009. - http://news.bbc.co.uk/2/hi/africa/8019084.stm

British BroadCASting Corporation (BBC) (2010a), Somali pirates receive record ransom for ships release, BBC News Online, 6 November 2010. - http://www.bbc.co.uk/news/ world-africa-11704306

British BroAdCASTING CoRPoration (BBC) (2010b), Freed Somali pirates "probably died" - Russian source, BBC News Online, 11 May 2010. - http://news.bbc.co.uk/2/hi/africa/8675978.stm

Churchill R.R., Lowe A.V. (1999), The Law of the Sea, Third Ed. Manchester, Manchester Univ. Press.

Clottery P. (2010) ‘AMISOM Official Calls Somalia Troop Increase Positive', Voice of America News, 27 July 2010. - http://www1.voanews.com/english/new/africa/AMISOM-OfficialCalls-Somalia-Troop-Increase_Positive--99399344.html?utm_source=twitterfeed\&utm_ medium=twitter

Danilova L. (2010), Hijacked Russian tanker freed, crew safe, pirate dead, Reuters, 6 May 2010. - http://af.reuters.com/article/topNews/idAFJOE64500820100506?sp=true

Epoch Times (2010), Kenya Opens Pirate Court, Epoch Times, 13 July 2010. - http://www. theepochtimes.com/n2/contact/view/38023/

Greste P. (2009), Puntland Turns Against Somali Pirates, BBC News Online, 31 May 2009. http://news.bbc.co.uk/2/hi/africa/807288.stm 
Harding A. (2009), Postcard from Somali pirate capital, BBC New Online, 16 June 2009. http://news.bbc.co.uk/2/hi/africa/8103585.stm

Houreld K. (2010), Ships fill up with pirates after Kenya balks, Navy Times, 15 April 2010.http://www.navytimes.com/news/2010/04/ap_pirates_kenya_041510/

House of Lords (2010), Combating Somali Piracy: the EU's Naval Operation Atalanta, 23 April 2010. - http://www.publications.parliament.uk/pa/ID200910/IDSelect/ IDeucom/103/10304.htm

Hoyle P. (2000), Somaliland: Passing the Statehood Test? In: Boundary and Security Bull., 8, 3 (Autumn), pp. 80-91.

Hyer STANDARD (2009), Clinton vows to freeze pirate assets, 15 April 2009. - http://hyerstand ard.com/2009/04/15/clinton-vows-to-freeze-pirate-assets/

International Maritime Bureau (IMB) (2007), Piracy and Armed Robbery Against Ships Annual Report 1 January - 31 December 2006. London, ICC Intern. Maritime Bureau.

International Maritime Bureau (IMB) (2009), Piracy and Armed Robbery Against Ships Annual Report 1 January - 31 December 2008. London, ICC Intern. Maritime Bureau.

International Maritime Bureau (IMB) (2010a), First vessel hijacked by pirates in the Red Sea, IMB Piracy Reporting Centre, News, 6 July 2010, ICC Intern. Maritime Bureau, London. - http://www.icc-ccs.org/index.php? option=com_content\&view $=$ article $\& i d=$ 417:first-vessel-hijacked-by-pirates-in-the-red-sea\&catid=60:news\&Itemid=51

International Maritime Bureau (IMB) (2010b), Best Management Practices to Deter Piracy off the Coast of Somalia and in the Arabian Sea Area, Version 3 (BMP3), June 2010. - http://www.icc-ccs.org/index.php? option=com_content $\&$ view $=$ category \&layout $=$ blog \&id $=59 \&$ Itemid $=6$

International Maritime Bureau (IMB) (2010c), Pirates face new resistance as navies strike back, says IMB, Piracy Reporting Centre, News, 15 July 2010, ICC Intern. Maritime Bureau, London. - http: $/ / w w w . i c c-c c s . o r g / i n d e x . p h p ?$ option $=$ com_content $\& v i e w=$ article $\& i d=418$ :pirates-face-new-resistance-as-navies-strike-back-says-imb\&catid=60:news\&Itemid=51

International Maritime Bureau (IMB) (2010d), Pirates intensify attacks in new areas, with first Somali hijacking reported in Red Sea, IMB Piracy Reporting Centre, New, 18 October 2010, ICC Intern. Maritime Bureau, London. - http://www.icc-ccs.org/index. php? option=com_content $\&$ view $=$ article $\&$ id $=424$ :pirates-intensify-attacks-in-new-areas with-first-somali-hijacking-reported-in-red-sea\&catid=60:news\&itemid=51

International Maritime Bureau (IMB), Piracy reporting centre (2010), Piracy Prone Areas and Warnings. - http://www.icc-ccs.org/index.php?option=com_content\&view=articl $e \& i d=70 \&$ Itemid $=58$

International Maritime Organization (IMO) (2010), Piracy in the waters off the coast of Somalia. $-w w w . i m o . o r g / h o m e . a s p ?$ topic_id $=1178$

IOL News (2010), Tanzania agrees to prosecute Somali pirates, IOL News, 20 May 2010 - - http://

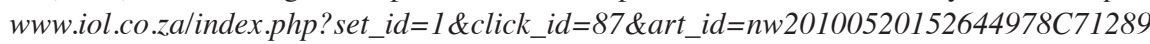
50

Jennings T. (2001), Controlling Access in the Absence of a Central Government: The Somali Dilemma. In: Ocean Yearbook, 15, pp. 403-427.

Jurist Legal News and Research (2010), Dutch Court Sentences Somali Pirates to 5 Years in Prison, Jurist Legal News and Research, 18 June 2010. - http://jurist.org/paperchase/ 2010/06/dutch-court-sentences-somalia-pirates-to-5-years-in-prison.php

Ku J. (2010), US will Prosecute More Pirates in the Eastern District of Virginia, Opinio Juris, 22 April 2010. - http://opiniojuris.org/2010/04/22/us-will-prosecute-more-pirates-inthe-eastern-district-of-virginia 
KulmiYe A.J. (2001), Militia vs Trawlers: Who is the Villain?, The East African Magazine, 9 July 2001. - http://www.ecop.infor/english/ind-oce-pir-somalia.htm

Lehr P., Lehmann H. (2007), Somalia - Pirates New Paradise. In: Lehr P. (ed.), Violence at Sea, pp. 1-22. London, Routledge.

Malkhadir M.M. (2010), EU: Pirates release oil supertanker, Associated Press, 18 January 2010. - http://customwire.ap.org/dynamic/stories/P/PIRACY?SITE $=$ FLTAM\& $S E C T I O N=H O M E \& T E M P L A T E=D E F A U L T \& C T I M E=2010-01-18-06-04-17$

Mesoy A. (2006), Somalia in the Verge of War. In: Protocol Strategic Insights, 5 (November/ December), pp. 18-25.

Mwangura A. (2005), Indian Ocean Piracy: Somalia. - http://www.ecop.infolenglish/indoce-pir-somalia.htm

NATO (2009), The Growing Threat of Piracy to Regional and Global Security, Parliamentary Assembly. Committee Report 169 CDS 09 E, 2009 Annual Session, paragraph 72. http://www.nato-pa.int/Default.asp/SHORTCUT $=1770$

O'Connell D.P. (1984), The International Law of the Sea, Vol. II. Oxford, Clarendon Press.

Potgieter T., Schofield C.H. (2010), Poverty Poaching and Pirates: Geopolitical Instability and Maritime Insecurity off the Horn of Africa. In: Journal of the Indian Ocean Region, 6,1, pp. 86-112.

Republic of Somalia, Law No. 57 on the Territorial Sea and Ports, 10 September 1972, Article1(1). - http://www.un.org/Depts/los/LEGISLATIONANDTREATIES/PDFFILES/ SOM_1972_Law.pdf

Roach J.A., Sмith R.W. (1996), United States Responses to Excessive Maritime Claims. The Hague, Martinus Nijhoff.

Ross W. (2009), Somali navy chief: World's worst job?, BBC News Online, 16 June 2009. http://news.bbc.co.uk/2/hi/africa/8096137.stm

Saul J. (2009), Shippers weigh armed response to Somali piracy, Reuters, 3 June 2009. - http:// af.reuters.com/article/somaliaNews/idAFL3102486620090603? sp=true

Schofield C.H. (2007), Plaguing the waves - Rising piracy threat off the Horn of Africa. In: Jane's Intelligence Review, 19, 7 (July 2007), pp. 45-47.

Schofield C.H. (2008), Plundered Waters: Somalia's maritime resource insecurity. In: Doyle T., Risely M. (eds.), Crucible for Survival: Environmental Security in the Indian Ocean Region, pp. 102-115. New Brunswick - New Jersey - London, Rutgers Univ. Press.

SCHofield C.H. (2009), The Other "Pirates" of the Horn of Africa, RSIS Commentary (Singapore: S. Rajaratnam School of Intern. Studies (RSIS), 5 January).

SChofield C.H., Warner R. (forthcoming), Scuppering Somali Piracy: Global Responses and Paths to Justice. In: Forbes A. (ed.), Australia's Response to Piracy: Legal Issues (= Papers in Australian Maritime Affairs, 31), Canberra, Sea Power Centre - Australia.

SomaliPress (2009), Somalia President Endorses Puntland Agreement, SomaliPress.com, 30 September 2009. - http://www.somalipress.com/news/2009-sep-30/somalia-presidentendorses-puntland-agreement.html

SMH (2009b), Admiral stunned by “very good" pirates, 18 November 2009. - http://www.smh.com. au/news/world/admiral-stunned-by-very-good-pirates/2008/11/18/1226770413138.html

Sмiтн L. (2010), Personal communication with crewmember of seismic survey vessel transiting the Gulf of Aden in August 2010, 23 August 2010.

Sydney Morning Herald (SMH) (2009), Somali pirates free German gas tanker, 29 March 2009. - http://news.smh.com.au/breaking-news-world/somali-pirates-free-german-gastanker-20090329-9f46.html

The Global Herald (2010), Seychelles: Government Agrees to Try Somali Pirates, 13 May 2010. - http://theglobalherald.com/seychelles-government-agree-to-try-Somali-pirates/3529 
The Guardian (2010), Piracy trial starts in the Netherlands, 25 May 2010. - http://www. guardian.co.uk/world/2010/may/25/somalis-piracy-trial-netherlands

The Telegraph (2009), America sets up new antipiracy naval force', 8 January 2009.

ThisDay (2010), Tanzanian military equipment for hire? ThisDay, 13 January 2010. - http:// www.thisday.co.tz/? l=10533

United Nations (1983), The Law of the Sea, UN Document UN/Doc.A/CONF.62/122, New York, United Nations.

United Nations Conference on Trade and Development (UNCTAD) (2008), Review of Maritime Transport 2008, Geneva, UNCTAD.

United Nations, Division for Ocean Affairs and the Law of the Sea, Office of Legal Affairs (2010), Table of Claims to Maritime Jurisdiction (United Nations, Division for Ocean Affairs and the Law of the Sea, Office of Legal Affairs). - http://www.un.org/Depts/los/ LEGISLATIONANDTREATIES/PDFFILES/table_summary_of_claims.pdf(1 October 2010)

United Nations Environment Programme (UNEP) (2006), National rapid environmental desk assessment - Somalia, UN Environmental Programme, 2006. - http://www.unep .org/ tsunami/reports/TSUNAMI_SOMALIA_LAYOUT.pdf

United Nations' Food and Agriculture Organization (FAO) (2010), Somalia Fishery sector overwiew, Rome. - http://www.fao.org/fi/website/FiRetrieveAction.do?dom $=$ countrysector $\& x m l=F I-C P \_80 . x m l \& l a n g=e n$

United Nations Refugee Agency (2010), UNHCR sounds alert on deteriorating humanitarian situation in Somalia, African Press Agency, 12 May 2010. - http://www.apanews.net/ apa.php?page $=$ show_article_eng\&id_article $=124125$ (7 June 2010)

United Nations Security Council (UNSC) (2008a), Resolution 1816, S/RES/1816 (2008), 2 June 2008. - http://www.un.org/Docs/sc/unsc_resolutions08.htm

United Nations Security Council (UNSC) (2008b), Resolution 1838, S/RES/1838(2008), 7 October 2008. - http://www.un.org/Docs/sc/unsc_resolutions08.htm

United Nations Security Council (UNSC) (2008c), Resolution 1846 (2008), S/RES/1846(2008), 2 December 2008. - http://www.un.org/Docs/sc/unsc_resolutions08.htm

United Nations Security Council (UNSC) (2008d), Resolution 1851 (2008), S/RES/1851 (2008), 16 December 2008. - http://www.un.org/Docs/sc/unsc_resolutions08.htm

United Nations Security Council (UNSC) (2010), Resolution 1918 (2010), S/RES/1918 (2010), 27 April 2010. - http://www.un.org/Docs/sc/unsc_resolutions10.htm

United States (2010), Executive Order 13536, 12 April 2010. - http://edocket.access.gpo. gov/2010/pdf/2010-8878.pdf

Voice of America (VOA) News (2009), Somalia Government, Puntland Trade Accusations, VOA News.com (Somali). - http://wwwl .voanews.com/somali/news/news-makers-in-english/ TFG-Puntland-Deadlocked-70067967.html

von Hoesslin K. (2006), Making sense of Somalia's anarchic waters, Philippine Star Online, 25 March 2006.

W ArdheErNews (2009), EU and Kenya sign deal on transfer of Somali Pirates, WardheerNews. com, 6 March 2009. - http://wardherrnews.com/News_09/March/06_eu_pirates.html

Westcott K. (2009), Pirates in the Dock, BBC News, 21 March 2009. - http://news.bbc.co.uk/2/ hilafrica/8059345.stm

World Food Programme (WFP) (2010), Somalia, World Food Programme Countries. - http:// www.wfp.org/countries/Somalia 
